\title{
Author Correction: Aging and Nutrition: Theories, Consequences, and Impact of Nutrients
}

\author{
Nassifatou Koko Tittikpina ${ }^{1}$ (D) - Abdul-raouf Issa ${ }^{1} \cdot$ Mouhoudine Yerima $^{1} \cdot$ Affo Dermane $^{1} \cdot$ Sika Dossim $^{1}$. \\ Mounerou Salou ${ }^{1}$ - Batomayena Bakoma ${ }^{1}$ - Aboudoulatif Diallo ${ }^{1}$ - Yao Potchoo ${ }^{1}$. Yerim Mbagnick Diop ${ }^{1,2}$
}

Published online: 6 June 2019

(C) Springer Nature Switzerland AG 2019

\section{Author Correction: Current Pharmacology Reports https://doi.org/10.1007/s40495-019-00185-6}

The original version of this article unfortunately contained a mistake in the author group section. The correct name of the seventh author is "Batomayena Bakoma."

The author apologizes for this oversight and for any confusion it may have caused.

Publisher's Note Springer Nature remains neutral with regard to jurisdictional claims in published maps and institutional affiliations.

The online version of the original article can be found at https://doi.org/ 10.1007/s40495-019-00185-6

Nassifatou Koko Tittikpina

Knassifatou@gmail.com

1 Department of pharmaceutical sciences (Département des sciences pharmaceutiques), Faculty of health sciences (Faculté des Sciences de la Santé), University of Lomé (Université de Lomé), BP :1515 Lomé, Togo

2 Laboratoire de Chimie Analytique et Bromatologie (LCAB), Faculté de Médecine, de Pharmacie et d'Odontologie, Université Cheikh Anta Diop de Dakar (UCAD), BP : 5005 Dakar, Sénégal 